\title{
Constructed Wetland-Microbial Fuel Cells for Sustainable Greywater Treatment
}

\author{
Ignacio Araneda ${ }^{1,2}$, Natalia F. Tapia ${ }^{2,3}$, Katherine Lizama Allende 1 (D) and \\ Ignacio T. Vargas $2,3, *$ (iD) \\ 1 Department of Civil Engineering, Universidad de Chile, 8370449 Santiago, Chile; \\ ignacio_ag91@hotmail.com (I.A.); klizama@ing.uchile.cl (K.L.A.) \\ 2 Centro de Desarrollo Urbano Sustentable (CEDEUS), 7520246 Santiago, Chile; netapia@uc.cl \\ 3 Department of Hydraulic and Environmental Engineering, Pontificia Universidad Católica de Chile, \\ 7820436 Santiago, Chile \\ * Correspondence: itvargas@ing.puc.cl; Tel.: +56-226-864218
}

Received: 6 June 2018; Accepted: 10 July 2018; Published: 14 July 2018

\begin{abstract}
Greywater reuse through decentralized and low-cost treatment systems emerges as an opportunity to tackle the existing demand for water. In recent years, constructed wetlands (CW) systems and microbial fuel cells (MFCs) have emerged as attractive technologies for sustainable wastewater treatment. In this study, constructed wetland microbial fuel cells (CW-MFCs) planted with Phragmites australis were tested to evaluate the potential of combining these two systems for synthetic greywater treatment and energy recovery. Open (CW) and closed circuit (CW-MFCs) reactors were operated for 152 days to evaluate the effect of energy recovery on the removal of soluble chemical oxygen demand (sCOD), nutrients and total suspended solids (TSS). Results indicate no significant differences for SCOD and phosphate removal efficiencies. CW-MFCs and CW reactors presented sCOD removal efficiency of $91.7 \pm 5.1 \%$ and $90 \pm 10 \%$ and phosphate removal efficiencies of $56.3 \pm 4.4 \%$ and $61.5 \pm 3.5 \%$, respectively. Nitrate removal efficiencies were higher in CW: $99.5 \pm 1 \%$ versus $86.5 \pm 7.1 \%$ in CW-MFCs, respectively. Energy generation reached a maximum power density of $33.52 \pm 7.87 \mathrm{~mW} \mathrm{~m}^{-3}$ and $719.57 \pm 67.67 \mathrm{~mW} \mathrm{~m}^{-3}$ at a poised anode potential of $-150 \mathrm{mV} \mathrm{vs}$. $\mathrm{Ag} / \mathrm{AgCl}$. Thus, our results suggest that the incorporation of MFC systems into constructed wetlands does allow energy recovery while providing effective greywater treatment.
\end{abstract}

Keywords: microbial fuel cell; constructed wetland; greywater; wastewater treatment; water reuse

\section{Introduction}

Water is a critical resource that is required for food production, energy generation, and industrial processes among other applications. Extreme weather due to climate change is projected to affect the availability and quality of water [1]. For this reason, the efficient use and management of water resources, including water reuse, is necessary. Greywater is a promising resource, accounting for $50-80 \%$ of sewage [2], which could be treated for reuse in green areas or used as wash water [3]. Physical, chemical, and biological technologies are used for greywater treatment. Among several biological treatments, constructed wetlands have been considered the most cost-effective and environmentally friendly technology used for this purpose [2].

Constructed wetlands (CW) systems take advantage of processes that occur naturally in wetlands, allowing treatment that includes filtration and adsorption by plants and aerobic/anaerobic degradation by microorganisms [4]. Thus, the reactions that occur in wetland environments generate aerobic and anaerobic zones that can be utilized for the implementation of microbial fuel cells (MFCs). MFCs are bioelectrochemical systems that transform chemical energy in organic residues into electricity [5]. 
In these systems, organic compounds are oxidized releasing protons and electrons. The electrons are transferred to the anode and transported through an external circuit to the cathode, where together with the protons they are used to reduce an acceptor (usually oxygen).

$\mathrm{CW}$ is a technology widely implemented to treat different types of wastewater from pilot to full-scale applications [6]. In contrast, and even though MFCs have been used to treat a wide range of wastewater types [6,7], this technology is still in its infancy and has not been completely developed to full-scale reactors. Both technologies have been evaluated to treat greywater [8-10], but the hybrid system (i.e., constructed wetland microbial fuel cells (CW-MFCs)) is an emerging technology that has only been applied for wastewater treatment and not for greywater treatment [11-14]. Most of CW-MFCs have been built using carbon based materials as the electrode (e.g., graphite and activated carbon granules) due to their low cost, corrosion resistance and high specific surface area [15]. Different wetland plants have been used, including Phragmites australis, usually operated under up-flow conditions to maximize redox potential gradient across the substratum [16]. Preliminary studies indicated that CW-MFCs presented similar performance to that of $\mathrm{CW}$ in terms of chemical oxygen demand (COD) removal efficiency (around 75\%) [16]. However, recent studies have shown that including the MFC component in CW improved COD removal efficiency [16]. In addition, CW-MFCs allow energy generation, reporting maximum power densities that reach up to $302 \mathrm{~mW} \mathrm{~m}^{-3}$ [17]. This suggests that CW-MFCs could be a sustainable alternative for greywater treatment.

In this study, we assessed the performance of CW-MFCs in terms of their capability of removing organic matter and nutrients from synthetic greywater while energy is recovered at the same time.

\section{Materials and Methods}

\subsection{System Configuration}

Four reactors were built and operated in this study. Each reactor consisted of a $10 \mathrm{~L}$ acrylic column (20 cm diameter and $32 \mathrm{~cm}$ height) with five sampling points located at 6, 13, 18, 22 and $26 \mathrm{~cm}$ from the bottom of the reactor. Two layers of gravel (particle size: $0-4.75 \mathrm{~mm}, 4.75-9.53 \mathrm{~mm}, 9.53-12.7 \mathrm{~mm}$, $12.07-19.05 \mathrm{~mm}$ ) were used as supporting medium for anode $(8 \mathrm{~cm}$ height$)$ and cathode $(6 \mathrm{~cm}$ height $)$ electrodes. These electrodes consisted of two layers of synthetic graphite granules (2-12 mm diameter) (Asbury Carbons) having different heights ( 6 and $2 \mathrm{~cm}$ for anode and cathode respectively). Graphite rod and titanium wires were used to connect anode and cathode with an external resistance of $1 \mathrm{k} \Omega$ in two of the four reactors. As such, two conditions were evaluated: open (CW) and closed (CW-MFCs) circuit. Finally, two stems of Phragmites australis were planted in each reactor above the cathode using zeolite (clinoptilolite-mordenite, particle size: $0-0.173 \mathrm{~mm}, 0.2-1 \mathrm{~mm}, 1.5-3 \mathrm{~mm}, 3-5 \mathrm{~mm}, 5-8 \mathrm{~mm}$, 8-10 mm, 10-15 mm, 15-30 mm) as supporting medium (Figure 1).
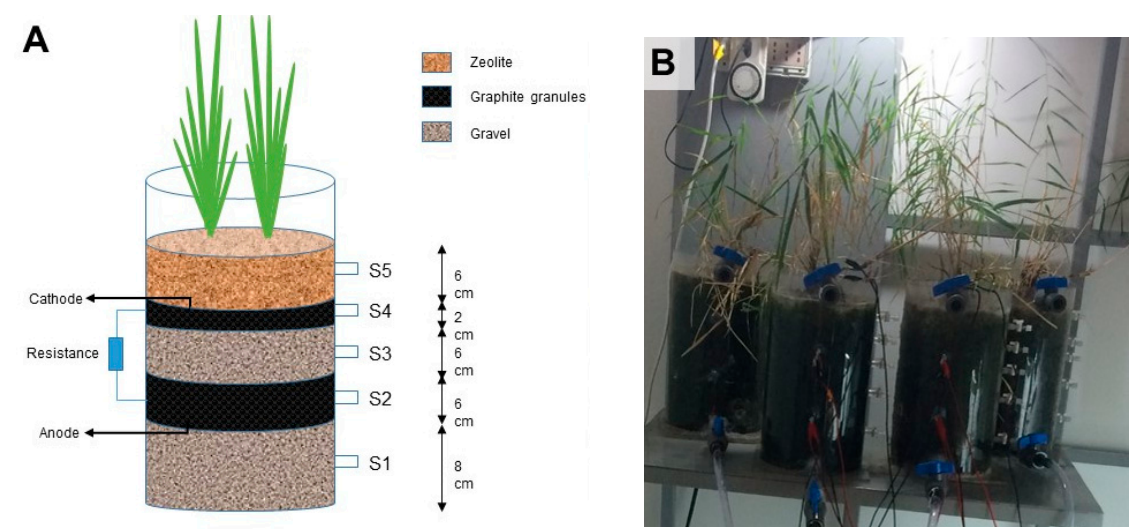

Figure 1. Constructed wetland-microbial fuel cell (CW-MFC) built using P. australis. (A) Diagram of the reactor, where S1, S2, S3, S4, and S5 are sampling ports located in each layer; (B) Photograph of the four reactors. 


\subsection{Synthetic Greywater}

The composition of the synthetic greywater used in this study was based on Arunbabu et al. [18]. The $\mathrm{NaHCO}_{3}$ concentration was increased so as to maintain neutral conditions during operation. Synthetic greywater was prepared for each batch cycle (i.e., 17 times) by adding the following reagents per liter of distilled water: $100 \mathrm{mg} \mathrm{C}_{3} \mathrm{H}_{6} \mathrm{O}_{3} ; 100 \mathrm{mg} \mathrm{C}_{6} \mathrm{H}_{10} \mathrm{O}_{5} ; 50 \mathrm{mg} \mathrm{NaC}{ }_{12} \mathrm{H}_{25} \mathrm{SO}_{4} ; 200 \mathrm{mg} \mathrm{C}_{3} \mathrm{H}_{8} \mathrm{O}_{3}$; $136.7 \mathrm{mg} \mathrm{NaHCO} 3 ; 50 \mathrm{mg} \mathrm{Na} 2 \mathrm{SO}_{4} ; 36.08 \mathrm{mg} \mathrm{KNO}$; and $21.95 \mathrm{mg} \mathrm{K}_{2} \mathrm{HPO}_{4}$. The characterization of the obtained greywater is detailed in Table 1.

Table 1. Physicochemical characterization of the influent synthetic greywater.

\begin{tabular}{ccc}
\hline Parameter & Unit & Mean \pm SD $^{\mathbf{1}}$ \\
\hline $\mathrm{pH}$ & - & $7.1 \pm 0.4$ \\
Electrical conductivity & $\mu \mathrm{S} / \mathrm{cm}$ & $277.8 \pm 37.6$ \\
Turbidity & $\mathrm{NTU}$ & $15.4 \pm 8.3$ \\
COD, total & $\mathrm{mg} / \mathrm{L}$ & $477.8 \pm 70.3$ \\
COD, soluble & $\mathrm{mg} / \mathrm{L}$ & $380.4 \pm 38.7$ \\
Total suspended solids & $\mathrm{mg} / \mathrm{L}$ & $95.9 \pm 5.2$ \\
Nitrate & $\mathrm{mg} / \mathrm{L}$ & $7.1 \pm 0.8$ \\
Phosphate & $\mathrm{mg} / \mathrm{L}$ & $19.9 \pm 2.6$ \\
\hline
\end{tabular}

${ }^{1}$ Mean and standard deviation (SD) were calculated using 12 measurements, except for total suspended solids and nutrients (nitrate and phosphate), which considered two and three measurements, respectively.

\subsection{System Operation}

The four reactors were operated in a controlled temperature room as batch cycle-mode for 152 days. The mean temperature during this period was $30 \pm 2{ }^{\circ} \mathrm{C}$ (mean $\pm \mathrm{SD}$ ). Illumination was provided using one white lamp of $30 \mathrm{~W}$ during a light period of $12 \mathrm{~h}$ per day.

The operation consisted of four different periods: (i) inoculation; (ii) operation to evaluate COD removal; (iii) operation with potentiostatic assistance; and (iv) operation to evaluate total suspended solids (TSS) and nutrient removal, in which two reactors were run as CW and the other two as CW-MFC. During the first period (55 days), the reactors were inoculated along four batch cycles with hydraulic retention time (HRT) of 13, 8, 7, and 27 days, respectively. In the first three cycles, 100, 50 and $50 \mathrm{~mL}$ of primary effluent from a wastewater treatment plant together with $2.9,2.95$ and $2.95 \mathrm{~L}$ of synthetic greywater were added, respectively. For the fourth batch cycle, $100 \mathrm{~mL}$ of batch 3 effluent was mixed with $2.9 \mathrm{~L}$ of synthetic greywater and the mix was added to reactors. The second period consisted of two batch cycles with HRTs of 16 and 12 days, respectively. In the third period, the anode potential in CW-MFC reactors was poised at $-150 \mathrm{mV}$ versus $\mathrm{Ag} / \mathrm{AgCl}$ reference electrode using a potentiostat Interface 1000 (Gamry, Warminster, England) during five batch cycles with HRTs of 2, 2, 2, 31, 2 and 2 days. Finally, in the last period, five batch cycles with HRTs of 2, 2, 8, 8 and 8 days were operated. During the last two and three batch cycles, TSS and nutrient (nitrate and phosphate) removal were evaluated.

Cell voltage was measured continuously every $10 \mathrm{~min}$ in all CW-MFC reactors using a Keithley 2700 data acquisition system. Current density was normalized by the effective volume of the anode electrode using the following equation [11]:

$$
\mathrm{P}_{\mathrm{d}}=\mathrm{V}^{2} / v \mathrm{~V}_{\mathrm{an}} \mathrm{R}
$$

where $P_{d}$ is the normalized current density $\left(\mathrm{W} \mathrm{m}^{-3}\right), \mathrm{V}$ is the cells voltage (Volts), $v$ is the porosity (0.38 for graphite) [19], $\mathrm{V}_{\text {an }}$ is the volume of the anode $\left(\mathrm{m}^{3}\right)$, and $\mathrm{R}$ the external resistance $(\Omega)$.

\subsection{Chemical Analysis}

For each batch cycle, samples were collected from influent, effluent and S2, S3, and S4 sampling points (Figure 1) to analyze $\mathrm{pH}$, electric conductivity, turbidity, TSS, COD, soluble chemical oxygen 
demand (sCOD), nitrate, and phosphate. Electric conductivity, $\mathrm{pH}$ and turbidity were measured with a Sension5 $\mathrm{HACH}^{\circledR}$ conductivity sensor, Orion 720, Thermo $\mathrm{pH}$ meter and HI98703 HANNA ${ }^{\circledR}$ turbidimeter respectively. Total suspended solids were measured according to American Public Health Association (APHA) standard methods [20]. COD, sCOD, nitrate and phosphate were analyzed using a $\mathrm{HACH}^{\circledR}$ DRB200 spectrophotometer according to method 8000; 8039 and 8049, respectively. For sCOD determination, samples were filtered using 0.2 um filters.

\subsection{Statistical Analysis}

Mean values and standard deviation were reported for each analysis. To compare the treatment performance of CW and CW-MFCs, one way analysis of variance (ANOVA) tests were performed using Excel data analysis and a significance level of $\alpha=0.05$. This was done to detect significant differences between CW and CW-MFCs removal efficiencies of the following pollutants: SCOD, nitrate, phosphate and TSS.

\section{Results and Discussion}

\section{1. sCOD Removal}

Both CW and CW-MFCs systems were highly effective in the removal of SCOD, and significant differences were not detected $(p=0.77)$. A quick decrease in SCOD levels was observed in both systems during the first six days of each cycle. The sCOD removal efficiencies at day 12 for batch cycles five and six were $90 \pm 10 \%$ and $91.7 \pm 5.1 \%$ for CW and CW-MFC, respectively (Figure 2). COD removal efficiencies from wastewater using MFC-CW ranges from $64 \%$ to $99 \%[5,12,21,22]$. This wide range of COD removal efficiencies is due to different operational conditions and shows the role of the organic loading on CW-MFCs performance [16]. Indeed, Villaseñor et al. and Liu et al. reported performance variations when COD increase doubling the original concentration [23,24]. However, the effect of COD variations below $100 \mathrm{mg} \mathrm{L}^{-1}$, as those observed in this study, have not been syndicated as a key factor that could affect reactor performance. Regarding to COD removal efficiencies from greywater, this reached up to $94 \%$ using CW [8] and $71.63 \%$ using MFC [10]. Therefore, since the sCOD removal observed in CW-MFC during batch cycles five and six ranged from 81 to $99 \%$, the hybrid system (i.e., CW-MFC) arises as an attractive alternative for SCOD removal from synthetic greywater.

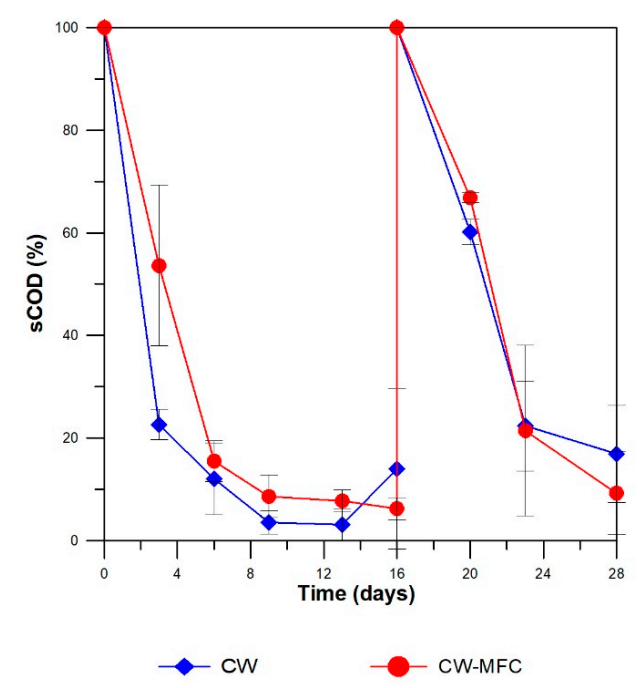

Figure 2. Mean percentage of soluble chemical oxygen demand (sCOD) within the CW (blue) and CW-MFC (red) reactors during batch 5 and 6. Error bars indicate the standard deviation calculated from six measurements. 
A similar increase in removal efficiency (i.e., percentage of sCOD removed) of the sample corresponding to the port located in the anode (sample point S2 in Figure 1) was observed for both types of reactors between the batch cycles before connecting the potentiostatic assistance and the last three batch cycles of fourth period, from $72.5 \pm 3.5 \%$ to $85.3 \pm 1.5 \%$ for $\mathrm{CW}$ and $60 \pm 1.41 \%$ to $75 \pm 5.57 \%$ for CW-MFCs. This suggest that posing the anode at $-150 \mathrm{mV}$ vs. Ag/ $\mathrm{AgCl}$ in CW-MFC reactors did not affect COD removal efficiency, and the increase observed in COD removal could be produced by the acclimation of bacteria to operational conditions and the evolution of the microbial community in the reactor. This phenomenon had been observed in MFC, where an power density increase is observed in the long-term [25].

\subsection{Nutrients and TSS Removal}

In wetlands, nitrate removal, occurs mainly by biological reaction, such as denitrification [11]. Nitrate removal was significantly higher $(p=0.01)$ in CW reactors than in CW-MFC reactors $(99.5 \pm 1 \%$ versus $86.5 \pm 7.1 \%$, respectively) (Figure 3 ). These differences could be explained due to anode and nitrate competition as electron acceptors in CW-MFC reactors. In consequence, part of the electrons were used for electricity generation (i.e., anode respiration) instead of nitrate reduction [26], which decreases nitrate removal.

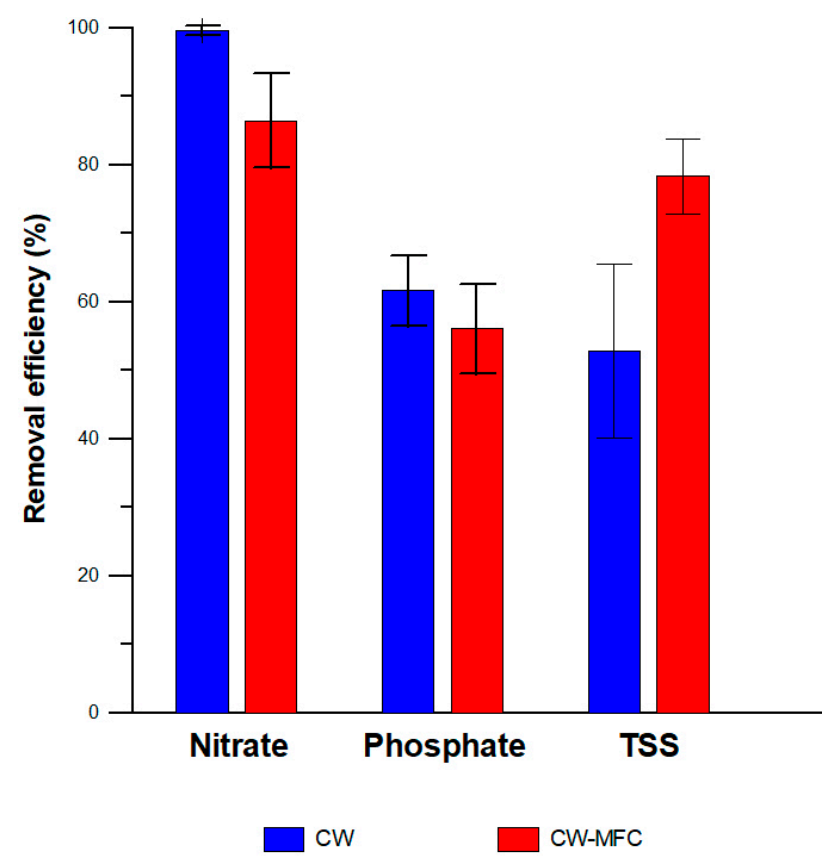

Figure 3. Mean nitrate and phosphate removal efficiency corresponding to the last three batch cycles, and total suspended solids (TSS) removal efficiency corresponding to the last batch cycle in constructed wetlands (CW) (blue) and CW-MFC (red) reactors. Error bars indicate the standard deviation calculated from four measurements for nitrate and phosphate, and from two measurements for TSS.

No significant differences in phosphate removal efficiency were observed $(p=0.11)$ between the two systems. Phosphate removal efficiency was $61.5 \pm 3.5 \%$ in $C W$ reactors and $56.3 \pm 4.4 \%$ in CW-MFC reactors (Figure 3). In CW systems, phosphate removal occurs mainly by adsorption/precipitation by filter media, uptake by plants and immobilization by microorganisms [27].

Regarding TSS removal, even though only two measurements were conducted, significant differences were not observed $(p=0.11)$. TSS removal was $52.9 \pm 12.7 \%$ and $78.4 \pm 5.5 \%$ for $\mathrm{CW}$ and CW-MFC, respectively (Figure 3). These values are lower than those reported by Ramprasad and Philip [8] in CW used to treat greywater, which included a pre-treatment (settling tank) unit, and slightly lower than those reported by Saumya et al. [9] in CW without pre-treatment. These authors 
reported TSS removal efficiencies from 80 to $94 \%$ and $81.95 \%$, respectively. This suggests the importance of including preliminary treatment units (e.g., sand filter and sedimentation tank) with CW or CW-MFC systems for complete greywater treatment.

\subsection{Electricity Generation}

Setting the anode potential had shown to influence extracellular electron transfer rate allowing to enhance current generation [28] and selecting anode-respiring bacteria, such as Geobacter sulfurreducens $[29,30]$, when the anode potential is poised around $-150 \mathrm{mV}$ vs. $\mathrm{Ag} / \mathrm{AgCl}$. When the anode was poised at $-150 \mathrm{mV}$ vs. $\mathrm{Ag} / \mathrm{AgCl}$, power density notably increased reaching a maximum value of $719.57 \pm 67.67 \mathrm{~mW} \mathrm{~m}^{-3}$ (Figure 4), which is around 20 times higher than the maximum value reached by the system without potentiostatic assistance $\left(33.52 \pm 7.87 \mathrm{~mW} \mathrm{~m}^{-3}\right.$ ) (Figure S1 in Supplementary Material). This value is higher than those reported by Doherty et al. $\left(280 \mathrm{~mW} \mathrm{~m}^{-3}\right)$ and Fang et al. (302 $\mathrm{mW} \mathrm{m}^{-3}$ ) for CW-MFCs treating wastewater [17,19] (Table 2), where the anode potential was not poised. Once potentiostatic assistance was disconnected (day 142), power density gradually dropped until it reached a value around $6 \mathrm{~mW} \mathrm{~m}^{-3}$ (Figure S1 in Supplementary Material). The results suggest that poised anode potential at $-150 \mathrm{mV}$ vs. $\mathrm{Ag} / \mathrm{AgCl}$ had no influence in performance of the reactor during the fourth period. However, to poise anode potential could allow raising the potential difference between electrodes, which were separated only by $6 \mathrm{~cm}$, improving current generation and the subsequent energy recovery. The distance between electrodes is important for increasing electricity generation in MFC systems. Song et al. [14] reported a lower power density in CW-MFCs when the distance between electrodes decreases from 20 to $10 \mathrm{~cm}$ [14]. When reducing the distance between electrodes, internal resistance decreases, but the dissolved oxygen in anode could not generate anoxic conditions suitable for exoelectrogenic microorganism, affecting power generation [14].

Table 2. Comparison of COD removal efficiency and power density between previous studies and this study.

\begin{tabular}{cccc}
\hline Reference & Plant Species & COD Removal Efficiency (\%) & Maximum Power Density \\
\hline Zhao et al. [5] & Phragmites australis & 76.5 & $9.4 \mathrm{~mW} \mathrm{~m}^{-2}$ \\
Wu et al. [12] & Iris pseudacorus & 99 & $9.6 \mathrm{~mW} \mathrm{~m}^{-2}$ \\
Liu et al. [31] & Ipomoea aquatic & 85.7 & $12.42 \mathrm{~mW} \mathrm{~m}^{-2}$ \\
Yadav et al. [21] & Canna indica & 75 & $15.73 \mathrm{~mW} \mathrm{~m}^{-2}$ \\
Oon et al. [11] & Typha latifolia & 91.2 & $93 \mathrm{~mW} \mathrm{~m}^{-3}$ \\
Doherty et al. [22] & Phragmites australis & 64 & $280 \mathrm{~mW} \mathrm{~m}^{-3}$ \\
Fang et al. [17] & Ipomoea aquatic & 94.8 & $302 \mathrm{~mW} \mathrm{~m}^{-3}$ \\
\hline & $87\left(^{*}\right)$ & $33.52 \pm 7.87 \mathrm{~mW} \mathrm{~m}^{-3}$ \\
This study & Phragmites australis & $92\left(^{* *}\right)$ & $719.57 \pm 67.67 \mathrm{~mW} \mathrm{~m}^{-3}(* * *)$ \\
\hline 1 Units vary according to what reported in each study. & $\left(^{*}\right)$ COD removal obtained in CW-MFC reactors. \\
$\left(^{* *}\right.$ COD removal obtained in CW reactors. $(* *)$ Power density obtained in CW-MFC reactors operated under \\
potentiostatic assistance.
\end{tabular}

The development of hybrid CW-MFC systems could improve the performance and sustainability of conventional CW used for sub-surface wastewater treatment. Its performance would be improved by including an alternative electron acceptor (i.e., anode electrode) in the anaerobic zone of the substratum, reducing methane production [32] and its effect on global warming [33]. Electricity recovery by CW-MFCs systems is another promising positive outcome expected from this technology. Further interdisciplinary research is required to reach power outputs in the order of magnitude required to load lighting, sensors, or other applications [34]. The use of poised potential anodes emerges as an opportunity to tackle this limitation and this article represents an effort on this direction. However, additional studies are needed to evaluate the efficiency of this strategy under long-term operation. 


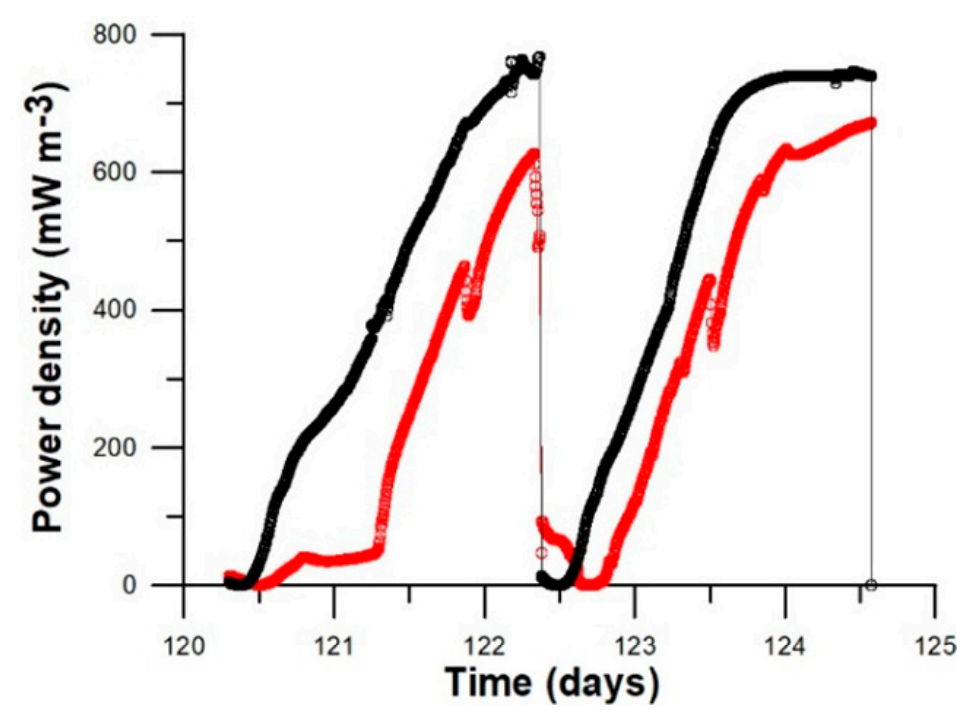

Figure 4. Power density obtained during the last two batch cycles of the third period, during potentiostatic assistance $-150 \mathrm{mV}$ vs. $\mathrm{Ag} / \mathrm{AgCl}$. Curves represent duplicate reactors.

\section{Conclusions}

This study evaluated the performance of CW-MFC as a greywater treatment and as an electricity generation system. Removal efficiencies of $91.7 \pm 5.1 \%, 86.5 \pm 7.1 \%$ and $56.3 \pm 4.4 \%$ were observed for sCOD, nitrate, and phosphate respectively. These results demonstrate the effectiveness of using a CW-MFC system to treat synthetic greywater. Power density increased when anode potential was poised at $-150 \mathrm{mV}$ vs. $\mathrm{Ag} / \mathrm{AgCl}$, reaching a maximum value of $719.57 \pm 67.67 \mathrm{~mW} \mathrm{~m}^{-3}$. This is the first study showing that CW-MFC could be a sustainable alternative for greywater treatment together with electricity production. Further studies are needed to evaluate poised potential strategies and optimize long-term performance of this technology for sustainable water treatment and energy recovery.

Supplementary Materials: The following are available online at http:/ / www.mdpi.com/2073-4441/10/7/940/s1, Figure S1: Performance of CW-MFC during the four periods (152 days of operation).

Author Contributions: All authors collaborated in this work. I.A., K.L. and I.V. conceived and designed the experiments; I.A. performed the experiments and analyzed the data; N.F.T. discussed the results and wrote the paper; K.L. and I.V. reviewed and edited the manuscript.

Funding: This research was funded by the CEDEUS center CONICYT/FONDAP/15110020.

Acknowledgments: The authors would like to thank Mauricio Medel for his support in the experimental work and Emily Hannon for her assistance in the writing process of this article. This work is part of the microbial fuel cells project in CEDEUS.

Conflicts of Interest: The authors declare no conflict of interest.

\section{References}

1. UN-Water. Climate Change Adaptation: The Pivotal Role of Water. In Policy Brief; UN-Water: Geneva, Switzerland, 2010.

2. Li, F.; Wichmann, K.; Otterpohl, R. Review of the technological approaches for grey water treatment and reuses. Sci. Total Environ. 2009, 407, 3439-3449. [CrossRef] [PubMed]

3. Wurochekke, A.A.; Harun, N.A.; Mohamed, R.M.S.R.; Kassim, A.H.B.M. Constructed wetland of Lepironia articulata for household greywater treatment. APCBEE Proced. 2014, 10, 103-109. [CrossRef]

4. Kadlec, R.H.; Wallace, S. Treatment Wetlands, 2nd ed.; CRC Press: Boca Raton, FL, USA, 2008.

5. Zhao, Y.; Collum, S.; Phelan, M.; Goodbody, T.; Doherty, L.; Hu, Y. Preliminary investigation of constructed wetland incorporating microbial fuel cell: Batch and continuous flow trials. Chem. Eng. J. 2013, 229, 364-370. [CrossRef] 
6. Wu, H.; Zhang, J.; Ngo, H.H.; Guo, W.; Hu, Z.; Liang, S.; Fan, J.; Liu, H. A review on the sustainability of constructed wetlands for wastewater treatment: Design and operation. Bioresour. Technol. 2015, 175, 594-601. [CrossRef] [PubMed]

7. Pant, D.; Van Bogaert, G.; Diels, L.; Vanbroekhoven, K. A review of the substrates used in microbial fuel cells (MFCs) for sustainable energy production. Bioresour. Technol. 2010, 101, 1533-1543. [CrossRef] [PubMed]

8. Ramprasad, C.; Philip, L. Surfactants and personal care products removal in pilot scale horizontal and vertical flow constructed wetlands while treating greywater. Chem. Eng. J. 2016, 284, 458-468. [CrossRef]

9. Saumya, S.; Akansha, S.; Rinaldo, J.; Jayasri, M.A.; Suthindhiran, K. Construction and evaluation of prototype subsurface flow wetland planted with Heliconia angusta for the treatment of synthetic greywater. J. Clean. Prod. 2015, 91, 235-240. [CrossRef]

10. Sajithkumar, K.J.; Ramasamy, E.V. Greywater treatment with simultaneus generation of energy using low-cost microbial fuel cells. Environ. Res. Eng. Manag. 2015, 71, 5-12. [CrossRef]

11. Oon, Y.-L.; Ong, S.-A.; Ho, L.-N.; Wong, Y.-S.; Dahalan, F.A.; Oon, Y.-S.; Lehl, H.K.; Thung, W.-E. Synergistic effect of up-flow constructed wetland and microbial fuel cell for simultaneous wastewater treatment and energy recovery. Bioresour. Technol. 2016, 203, 190-197. [CrossRef] [PubMed]

12. Wu, D.; Yang, L.; Gan, L.; Chen, Q.; Li, L.; Chen, X.; Wang, X.; Guo, L.; Miao, A. Potential of novel wastewater treatment system featuring microbial fuel cell to generate electricity and remove pollutants. Ecol. Eng. 2015, 84, 624-631. [CrossRef]

13. Wang, J.; Song, X.; Wang, Y.; Abayneh, B.; Ding, Y.; Yan, D.; Bai, J. Microbial community structure of different electrode materials in constructed wetland incorporating microbial fuel cell. Bioresour. Technol. 2016, 221, 697-702. [CrossRef] [PubMed]

14. Song, H.; Zhang, S.; Long, X.; Yang, X.; Li, H.; Xiang, W. Optimization of bioelectricity generation in constructed wetland-coupled microbial fuel cell systems. Water 2017, 9, 185. [CrossRef]

15. Li, W.-W.; Sheng, G.-P. Microbial fuel cells in power generation and extended applications. In Biotechnology in China III: Biofuels and Bioenergy; Bai, F.-W., Liu, C.-G., Huang, H., Tsao, G.T., Eds.; Springer: Berlin, Germany, 2012; pp. 165-197.

16. Doherty, L.; Zhao, Y.; Zhao, X.; Hu, Y.; Hao, X.; Xu, L.; Liu, R. A review of a recently emerged technology: Constructed wetland-Microbial fuel cells. Water Res. 2015, 85, 38-45. [CrossRef] [PubMed]

17. Fang, Z.; Song, H.-L.; Cang, N.; Li, X.-N. Performance of microbial fuel cell coupled constructed wetland system for decolorization of azo dye and bioelectricity generation. Bioresour. Technol. 2013, 144, 165-171. [CrossRef] [PubMed]

18. Arunbabu, V.; Sruthy, S.; Antony, I.; Ramasamy, E.V. Sustainable greywater management with Axonopus compressus (broadleaf carpet grass) planted in sub surface flow constructed wetlands. J. Water Process Eng. 2015, 7, 153-160. [CrossRef]

19. Doherty, L.; Zhao, Y.; Zhao, X.; Wang, W. Nutrient and organics removal from swine slurry with simultaneous electricity generation in an alum sludge-based constructed wetland incorporating microbial fuel cell technology. Chem. Eng. J. 2015, 266, 74-81. [CrossRef]

20. American Public Health Association; American Water Works Association; Water Environment Federation. Standard Methods for the Examination of Water and Wastewater; American Public Health Association: Washington, DC, USA, 2005.

21. Yadav, A.K.; Dash, P.; Mohanty, A.; Abbassi, R.; Mishra, B.K. Performance assessment of innovative constructed wetland-microbial fuel cell for electricity production and dye removal. Ecol. Eng. 2012, 47, 126-131. [CrossRef]

22. Doherty, L.; Zhao, X.; Zhao, Y.; Wang, W. The effects of electrode spacing and flow direction on the performance of microbial fuel cell-constructed wetland. Ecol. Eng. 2015, 79, 8-14. [CrossRef]

23. Villaseñor, J.; Capilla, P.; Rodrigo, M.A.; Cañizares, P.; Fernández, F.J. Operation of a horizontal subsurface flow constructed wetland-Microbial fuel cell treating wastewater under different organic loading rates. Water Res. 2013, 47, 6731-6738. [CrossRef] [PubMed]

24. Liu, S.; Song, H.; Wei, S.; Yang, F.; Li, X. Bio-cathode materials evaluation and configuration optimization for power output of vertical subsurface flow constructed wetland-Microbial fuel cell systems. Bioresour. Technol. 2014, 166, 575-583. [CrossRef] [PubMed] 
25. Aelterman, P.; Rabaey, K.; Pham, H.T.; Boon, N.; Verstraete, W. Continuous electricity generation at high voltages and currents using stacked microbial fuel cells. Environ. Sci. Technol. 2006, 40, 3388-3394. [CrossRef] [PubMed]

26. Sukkasem, C.; Xu, S.; Park, S.; Boonsawang, P.; Liu, H. Effect of nitrate on the performance of single chamber air cathode microbial fuel cells. Water Res. 2008, 42, 4743-4750. [CrossRef] [PubMed]

27. Park, J.-H.; Wang, J.J.; Kim, S.-H.; Cho, J.-S.; Kang, S.-W.; Delaune, R.D.; Seo, D.-C. Phosphate removal in constructed wetland with rapid cooled basic oxygen furnace slag. Chem. Eng. J. 2017, 327, 713-724. [CrossRef]

28. Ishii, S.I.; Suzuki, S.; Norden-Krichmar, T.M.; Phan, T.; Wanger, G.; Nealson, K.H.; Sekiguchi, Y.; Gorby, Y.A.; Bretschger, O. Microbial population and functional dynamics associated with surface potential and carbon metabolism. ISME J. 2014, 8, 963-978. [CrossRef] [PubMed]

29. Torres, C.I.; Krajmalnik-Brown, R.; Parameswaran, P.; Marcus, A.K.; Wanger, G.; Gorby, Y.A.; Rittmann, B.E. Selecting anode-respiring bacteria based on anode potential: Phylogenetic, electrochemical, and microscopic characterization. Environ. Sci. Technol. 2009, 43, 9519-9524. [CrossRef] [PubMed]

30. Wei, J.; Liang, P.; Cao, X.; Huang, X. A new insight into potential regulation on growth and power generation of Geobacter sulfurreducens in microbial fuel cells based on energy viewpoint. Environ. Sci. Technol. 2010, 44, 3187-3191. [CrossRef] [PubMed]

31. Liu, S.; Song, H.; Li, X.; Yang, F. Power generation enhancement by utilizing plant photosynthate in microbial fuel cell coupled constructed wetland system. Int. J. Photoenergy 2013, 2013, 10. [CrossRef]

32. Arends, J.B.A.; Speeckaert, J.; Blondeel, E.; De Vrieze, J.; Boeckx, P.; Verstraete, W.; Rabaey, K.; Boon, N. Greenhouse gas emissions from rice microcosms amended with a plant microbial fuel cell. Appl. Microbiol. Biotechnol. 2014, 98, 3205-3217. [CrossRef] [PubMed]

33. Maucieri, C.; Barbera, A.C.; Vymazal, J.; Borin, M. A review on the main affecting factors of greenhouse gases emission in constructed wetlands. Agric. For. Meteorol. 2017, 236, 175-193. [CrossRef]

34. Noori, M.T.; Ghangrekar, M.M.; Mukherjee, C.K. Sediment microbial fuel cell and constructed wetland assisted with it: Challenges and future prospects. In Microbial Fuel Cell: A Bioelectrochemical System That Converts Waste to Watts; Das, D., Ed.; Springer International Publishing: Cham, Switzerland, 2018; pp. 335-352.

(C) 2018 by the authors. Licensee MDPI, Basel, Switzerland. This article is an open access article distributed under the terms and conditions of the Creative Commons Attribution (CC BY) license (http:/ / creativecommons.org/licenses/by/4.0/). 